\title{
Fear and Loathing Down Under: Australian Refugee Policy and the National Imagination
}

\author{
RichARD WAZANA
}

\begin{abstract}
This paper looks at Australia's refugee policy in light of incidents that took place in the summer of 2001, with the refugees aboard the Tampa. Analyzing the discourse that resulted from these incidents, I show how Australia believes it is a nation under threat that prides itself as generously welcoming as many refugees as it can and who, of late, is only trying to protect its borders from so-called refugees who really are "queue jumpers." I contrast this view with what emerges from the facts: that Australia's racialized past makes it very easy for it to believe that it is under siege from refugees, and that it has done all that is legally possible to disinvest itself from its international obligations. This has meant turning boats away at sea, excising certain territories from its jurisdiction, and interning the refugees who arrive in Australia. Through this analysis, I argue that the current policy is a re-emergence of the earlier White Australia policy.
\end{abstract}

\section{Résumé}

Cet article examine la politique australienne sur le droit d'asile et les réfugiés à la lumière d'incidents survenus à l'été de 2001 avec les réfugiés du Tampa. J'analyse le discours qui a découlé de ces incidents et je montre comment l'Australie est convaincue qu'elle est une nation assiégée; qui, en même temps, s'enorgueillit du fait qu'elle accueille généreusement autant de réfugiés qu'elle le peut; et qui, récemment, a dû boucler ses frontières contre les soi-disant réfugiés qui ne sont en fait que des resquilleurs. Je compare ce point de vue avec les faits suivants : que le passé racisé de l'Australie fait que ce pays succombe facilement à la notion qu'il est assiégé par des réfugiés; et qu'il a fait tout ce qui était légalement possible pour se départir des ses obligations internationales. Cela s'est traduit par le renvoi de bateaux en haute mer, l'excision de certains territoires de sa juridiction et l'incarcération des réfugiés qui débarquent en Australie. À travers cette analyse, je soutiens que la présente politique est en fait une réapparition de la politique de l'Australie pour les Blancs.

Apparently nobody wants to know that contemporary history has created a new kind of human being - the kind that are put in concentration camps by their foes and in internment camps by their friends.

Hannah Arendt ${ }^{1}$

\section{Introduction}

The twentieth century is often referred to as the century of the refugee. Beginning with World War I, and brought to the world's attention after millions were forced to flee their homelands during and after World War II, and continuing into the last years of the past century with conflicts in central Africa and Europe, refugees are arguably the largest group needing protection in the world today. The United Nations states that there are somewhere around 15 million refugees in the world today, 80 per cent of whom are women and children, and that number is constantly growing due to new or aggravated conflicts all over the world. Moreover, according to Britain's Home Office, over 30 million people are smuggled across international borders annually in a trade worth between $\$ 12$ billion and $\$ 30$ billion (in U.S. dollars). ${ }^{2}$ 
In the western world, this refugee "crisis" plays out on many fronts. For instance, many countries from which refugees hail already have sizable populations in western Europe, North America, and Australia. Thus, for these communities, the issue is close to their heart, as they lobby their governments to accept more refugees. On the political front, the question of refugees, like immigration, is a delicate one that often has dire consequences during elections. Politicians understand that the public has a fragile tolerance for refugees, one that can tip quickly into intolerance when a boatload of refugees lands at their shores. In these instances, refugees become a political issue more than a humanitarian concern and the refugees themselves often get lost in the debate.

This is what has happened in Australia in recent years. Australia's geographical position, as a bastion of "western civilization" in a sea of Asian countries, has had important ramifications for the country's sense of identity and its fears around how many "foreigners" it is ready to receive. Invaded by Britain as a solution to its penal crisis - namely, that British jails were full, and it needed to find somewhere to house its convicts - Australia became a British colony, filled with convicts, soon followed by "voluntary" migrants needed to fill the land.

The presence of First Nations Peoples preceding that of the convicts is not often referred to other than in Australia's official multiculturalism policy. In fact, on the web site of Pauline Hanson's One Nation Party, Australia's extreme right-wing political party, the history section starts with the arrival of the convicts, in classic terra nullius tradition. First Nations Peoples, along with immigrants, are seen as financial burdens that the state has unfortunately decided to carry, to the detriment of Anglo-Australians. The One Nation Party holds special disdain for refugees who increasingly are landing - or, at least, trying to land - on Australian shores. Labeled "queue jumpers," refugees are depicted as scoundrels who have willingly paid exorbitant sums of money to get on "pleasure cruises" in search of a better country. ${ }^{3}$

The fact that the vast majority of these refugees come from countries where there is no "queue," where there is no Australian immigration or U.N office, and that upon arrival in Australia, up to 97 per cent of them are found to be Convention refugees ${ }^{4}$ - none of this seems to matter to a country that has increasingly been willing to use aggressive military maneuvers in order to keep these refugees at bay.

Indeed, the irony is that, once again, Australia is becoming a penal colony for involuntary migrants. The events leading up to what is now referred to as the "Tampa incident" reveal that Australia is ready to go to great lengths to keep refugees away from its shores. By setting up detention centers on Australian territories in the Pacific Ocean from which migrants can no longer apply for refugee status, as well as on impoverished islands, Australia is officially warehousing refugees - not to say smuggling - in an effort to process refugee applications away from its shores. What the Australian government has termed the "Pacific Solution" amounts to an overtly racist reaction to a few thousand persecuted refugees fleeing abominable conditions at home.

This paper will examine these recent developments as indicative of a new governmental approach to refugees, one that is unfortunately not used exclusively in Australia. Indeed, assaults at sea are common in the Mediterranean, where boatloads of North African and European migrants are routinely turned away, when they are lucky not to have drowned. ${ }^{5}$ I will attempt to bring Australian history back full circle, by showing that recent policies are indeed not new but recycled in a gentler form from its "White Australia" era, when official policy was to restrict immigration to white Europeans. I will moreover analyze popular discourse in Australia to show how Australia perceives itself as a nation under attack that is doing its best to protect "real" refugees while discouraging the inhuman smuggling of human beings. Finally, I will clearly show how the law is used to spatially restrict and control the movement of these refugees, keeping them away from the general population, in spaces that are clearly marked as degenerate.

\section{The Tampa Incident}

In August of 2001, over 1,500 refugees landed on Australian shores within eleven days. One boat, carrying 360 people, landed on Christmas Island on August 22, reportedly representing the biggest boatload of asylum seekers ever to reach Australia. ${ }^{6}$ Immediately, cries from the opposition party spread fears among the public that Australia had lost control over human smuggling. Five days later, on August 27, the government of Prime Minister John Howard showed that it was not going to let the opposition gain crucial votes, two months away from an election.

On August 27, the Tampa, a Norwegian freighter, entered Australian waters carrying 430 people, mostly from Afghanistan. The freighter had rescued the passengers from a sinking Indonesian ferry the previous day, and had been on its way to Singapore when the passengers demanded that they be taken to Christmas Island, an Australian territory in the Pacific Ocean, northeast of Australia. The Australian government refused them permission to enter its waters, claiming that they should have been taken to the nearest port of call. In effect, the Australian government claimed that this was essentially a problem to be resolved between the Indonesian government, whose ferry the refugees were 
initially transported on, and the Norwegian government, whose ship they were currently on.

The ridiculousness of this claim did not escape the ship's captain, who replied that there were not enough provisions on board to allow the migrants to reach the nearest Indonesian port. Howard's government responded that they would provide food, water, and medical supplies to allow the ship to make that trip. On August 29, the Tampa's captain took the ship into Australian waters, only to be stopped by Australian naval ships. Meanwhile, New Zealand had said they would examine the passengers' refugee claims so long as other countries did the same. The fact that Australia asked the tiny impoverished nation of East Timor to allow the ship to dock there in order to process the applications shows how determined the Howard government was to ensure that the migrants did not land on its shores.

Finally, on September 1, New Zealand and the tiny Pacific island of Nauru offered to house the refugees while they processed their applications. New Zealand proposed to take in 150 refugees - women, children, and families and Nauru would take the rest - mostly men. New Zealand agreed to accept all those found to be genuine refugees; Nauru, however, signed a Statement of Principles on September 10, stating that it would "provide a temporary processing site" for the migrants "with the understanding that the refugees would be processed and out of the country by May 2002."7 For this "humanitarian gesture," Australia would compensate Nauru with a $\$ 30$ million aid package, more money than they had received in the ten previous years combined. ${ }^{8}$

Before examining in depth the Australian government's "Pacific Solution," let us finish our story. On September 3, the passengers of the Tampa were transferred onto the Manoora, an Australian troopship, to be taken to Papua New Guinea, a journey that was expected to take a week, from where they would be transferred to Nauru and New Zealand. By then they had already spent nine days aboard the Tampa. Meanwhile, on September 7, Australian Coastwatch officials spotted a wooden boat on its way to Ashmore Reef. The Aceng was warned that its passengers faced detention and its crew up to twenty years in prison if it landed on Australian coast; when the boat refused to turn back, Australian Navy personnel boarded the boat in international waters. After agreeing to turn around, the Aceng played a cat and mouse game with Australian naval ships, until the Manoora intercepted it.

Australian naval crew transferred the 200 passengers believed to be Iraqis - of the Aceng onto the Manoora, and they continued on their way to Papua New Guinea. When Australia's Federal Court ruled that the government had illegally detained the group from the Tampa, the govern- ment filed an appeal, and Howard ordered the Manoora to bypass Papua New Guinea and head straight to Nauru. On September 17, the Manoora arrived at Nauru, the same day that the Federal Court ruled that the government had acted fairly in its early decision. ${ }^{9}$ On September 19, 100 of the Afghan refugees disembarked the Manoora and set foot on dry land for the first time in over one month. The plan was to disembark 100 at a time off the Manoora, to facilitate transportation to the refugee camps. However, things did not go as planned.

On September 21, the 200 Iraqi and Palestinian refugees refused to disembark, insisting that they be taken to Australia. The standoff lasted two weeks, and eventually Australian soldiers forcibly removed twelve remaining Iraqis, despite the fact that Nauru had insisted they would accept only voluntary arrivals. The first six Iraqis were removed after they were fooled into believing that there were Australian negotiators waiting for them; meanwhile, at home in Australia, one Australian politician suggested that food be withheld until they disembark. The Iraqis eventually held a sit-in on the bus transporting them to the refugee camps; the operation was suspended by the Nauru government, and it was only resolved after further negotiation. The entire incident was marked by intense media attention, harsh international condemnation, and much diplomatic rancour.

\section{The Refugee as the "Bricoleur"}

In attempting to understand why a country would go to such lengths to prevent a few unfortunate souls from landing on its shores, it is useful to draw upon Levi-Strauss's conceptual dichotomy of the "engineer" and the "bricoleur," as it is used by Radhika Mohanram. ${ }^{10}$ Mohanram conceptualizes the black body, the bricoleur, as being close to nature, irrational, emotional, and thus always raced. The engineer, on the other hand, is rational, scientific, mobile, and therefore always white. This notion of the raced body tied to the land is not novel, having been used to discredit urban Aboriginals, claiming that once they leave the land, they cease to be Aboriginal. This clever Catch-22 - urban aboriginals are no longer Aboriginals and thus relinquish their rights as Aboriginals, and Aboriginals who live on reserves have rights that are frozen in time, thus keeping them in abject poverty - has been used to further oppress First Nations Peoples in Canada.

Applied to the refugee, the concepts of "bricoleur" and "engineer" are very useful. Clearly, the refugee is the bricoleur and the white westerner is the engineer. I would go so far as to say that even when coming from "white" countries, as in the former Yugoslavia, the bodies of refugees are raced, to the same extent that Razack shows that the prostitute, whether white or black, is inherently raced, and thus 
blackened. ${ }^{11}$ The refugee, being a bricoleur, is not supposed to leave her land, all the more so since she is black and female. Mohanram writes that whereas "whiteness has the ability to move" and that "ability to move results in the unmarking of the body," "blackness is signified through a marking and is always static and immobilizing." 12 By plotting to leave her "degenerate" country and enter another, altogether "privileged" country without permission, the refugee transgresses the unstated law of the white man: "Thou shall not leave thy land (unless it serves our purpose)." The implicit corollary is that only the white man and his money shall travel and conquer. Moreover, this rebellion goes against the bricoleur's inherent relationship with nature, since, whereas the bricoleur is always pre-capitalistic, the engineer is "always located within modernity and capitalism." 13

Because the refugee transgresses, she must be intercepted and her body must be disciplined through internment, sending a clear message to other potential refugees of what awaits them should they dare leave their country and try their fate elsewhere. This has been played out on Australian soil and in Australian waters for the past ten years. The interception of boats, the internment of refugees, and the reprisals while interned can be seen as just actions on behalf of the white man putting the black man in his place. The internment camps in Australia and on remote islands thus serve not only as processing centers for sifting the "real" from the "fraudulent," but also for disciplining bodies out of place. As Mohanram states, "racial difference is also spatial difference, the inequitable power relationships between various spaces and places are rearticulated as the inequitable power relations between races." ${ }^{14}$ Moreover, as we shall see later, the conditions in these camps serve to mark these spaces, and the bodies who inhabit them, as degenerate, an essential part of this process.

What Mohanram shows through her discursive analyses of texts is that the condition of the refugee is intimately tied to that of the white settler. For one, we can argue, as many academics have, that "we are here because you were there," something that North Africans in France and South Asians in England have been saying for a long time. Moreover, Mohanram teases out this relationship, concluding that "the ecological immobility of the indigenous person ... functions to locate the settler as mobile, free, taking his environment with him in ships, boats, planes, and on the soles of his shoes." ${ }^{15}$ In what follows, I will attempt to demonstrate how these concepts play out in Australian refugee policy.

\section{Tropes at Play in Australia}

There are a number of tropes operating in Australia's media, political parties, and popular culture around refugees, bor- der protection, generosity, and Australian culture. These tropes make it possible for a large, sparsely populated country like Australia to call for a zero-sum immigration system. The first trope surrounds the belief that Australian culture (read, white and Anglo-Saxon) is under a constant and growing threat, and that without adequate measures for protection, it will vanish. This belief is not new. One of the first issues raised among settlers to Australia is whether a White Australia was possible; that is, whether the Australian climate and geography were suitable for white settlers. ${ }^{16}$ Today, this obsession has transformed itself into various measures meant to "protect" Australian culture and traditions, including an inhuman refugee policy.

A second trope, flowing directly from the first, is the belief that Australia, as a nation under attack, has the right to control its borders. Since Australia believes that it is under threat, it claims the right to protect itself, part of which means the right to close its borders should it choose to. The irony of the claim that Australia's sovereignty is being challenged is that the Australian government has amended existing laws and passed many new laws over the last ten years - although, especially during the past two years - in order to police, monitor, and control the "free" movement of refugees. To claim that it has lost its right to manage its internal affairs thus flies in the face of wellknown facts. Nonetheless, this illusion of self-preservation is important for the Australian collective imagination.

A third trope is the belief that those seeking asylum in Australia are not refugees but are people seeking a better life, and that even if they are refugees, they are queue jumpers. This trope, very popular among media, politicians, and the public, is used to devalue and trivialize an international human disaster at a local level and to justify changing existing human rights law at an international level. Moreover, the concept of queue jumping is used in total ignorance of the realities of different persecuted peoples abroad, as well as how western countries contribute to political and/or economic instability that results in forced migration. ${ }^{17}$

Finally, the fourth trope is built around Australia's generosity as a recipient of refugees, its international record, and its actions around stopping the illegal smuggling of refugees. Australia prides itself in believing, and constantly reiterates in all official publications, that it is the most generous country in the western world when it comes to accepting refugees. This stands in sharp contrast to the international publicity campaigns that have striven to deter refugees from attempting to enter Australia, legally or illegally, as well as to the conditions in detention camps where "illegal" refugees are detained upon arrival. Moreover, it has turned international condemnation on its side by argu- 
ing that what are perceived as harsh and inhumane measures meant to keep refugees out of Australia are really a concerted effort to put an end to the immoral human smuggling industry.

\section{"Australia under Attack"}

Let us start by examining the first trope - the belief that Australian culture is under threat. This is a dominant theme in the Australian psyche, one that goes back to the beginning of the twentieth century, when the Immigration Restriction Act was passed. The Act, which became law in 1901, was passed in the first year of Federation, in an attempt to prevent "coloured aliens" from entering Australia and restrict population growth to European settlers. The Act institutionalized the notion that Australians were members of the "British race," and officially started an immigration policy known as the White Australia Policy, which was kept in place until it was dismantled in 1973.

When the Immigration Restriction Act was passed, it mostly targeted Chinese immigration, but also immigration from the Pacific Islanders, who were the main labour force of the Queensland sugar industry. With the new law, it became imperative for the white man to take over that work, hence the obsession with climate and colonization. Australia also started to generate dialogue among medical and tropical experts, who researched whether a "White Australia” was possible. ${ }^{18}$

Writing about tropical medicine and colonialism, Alison Bashford says that the "Tropics" is "an idea which stands for hot spaces and also colonial spaces, where 'White man' does not quite fit in, but over which White man or White culture desires control." 19 She analyzes the public health discourse at the beginning of the century and claims that health, hygiene, and cleanliness were "an effective mode for the expression of racism" and became "one significant way in which the "whiteness" of White Australia was conceptualized." ${ }^{20}$ During the thirty years that followed, immigration policy and tropical research were intimately linked and colluded to defend the White Australia Policy. Part of this work, of course, consisted in pathologizing the Pacific Islanders and the Chinese as being contaminated and impure. These discourses continue today, as we will later see, and serve as justification for the internment of Afghani and Iraqi refugees.

Before these refugees appeared on Australian shores, it was largely Asian immigration that was cause for obsession. Morris argues that "phobic narratives" have dominated political debates in Australia for a long time, mostly centred on Indonesia. ${ }^{21}$ Media and political discourse around Indonesia have always focused on the concepts of fear and threat. By describing Indonesia as "having a population ten times that of Australia, as having a high birth rate ... and as having insufficient space for its large population on some of its islands," Indonesia is constantly depicted as a "dormant volcano" that could erupt any day. ${ }^{22}$

These phobic narratives, says Morris, are a combination of agoraphobia, a fear of opening up the Nation to a devouring Other, and claustrophobia, a fear of being shut away from a dynamic and prosperous world. Thus, while multiculturalism is celebrated and promoted by the Australian government's official policy, there is always the need of "reminding white Australians of the effects of excessive ethnic diversity" because the "open-ended project of multiculturalism threatens this capacity for action and self-confidence." ${ }^{23}$

This constant ambivalence towards multiculturalism, and the accompanying fears and anxiety, have been played out very recently in the context of soccer in Australia. Danforth, through extensive research into soccer commentating, press clippings, and public discourse, examines "Australian soccer as a source for the study of different narratives of the Australian nation." ${ }^{24}$

Known as an "ethnic" game that is often called "wogball," soccer in Australia is a perfect venue for examining the above-mentioned fears and anxieties around multiculturalism. Most club teams until recently had "ethnic" names, such as "South Melbourne Hellas," "Preston Makedonia," and "Heidelberg Alexander." For obvious reasons, these clubs are largely populated by European immigrants who have led the charge of Australian soccer for decades. This trend generated some fears among government officials that "old world" conflicts, such as that between Greece and Macedonia, were being played out on the soccer pitch. More importantly, they feared that as long as soccer was associated in the Australian consciousness with ethnicity, it would never enter the mainstream.

In an effort to Australianize the world's most popular game, and in an attempt to draw international sponsors and win lucrative television contracts, the Australian Soccer Federation decided to "de-ethnicize" soccer in Australia by abolishing what they called the "ethnic club system." According to the Federation, the club system, by which each individual club is associated with a particular ethnic group, has served to alienate the mainstream and is responsible for ethnic violence. As far back as the early eighties, the National Soccer League observed that the League needed "a new image ... so it can be identified as Australian." ${ }^{25}$ It also recommended that "club names should be amended where necessary to prevent ethnic recognition." ${ }^{26}$

In 1992, this resulted in the Australian Soccer Federation's decision to ban all teams with "ethnic" names from the National Soccer League. No team would be allowed to 
play if it carried the name of a foreign country, state, or place or any name with "political implications." Instead, teams would renamed based on the Australian region from which it came, so that "Hellas" was replaced by "South Melbourne." The commissioner of the Federation justified the move by saying that "the public perception is that we're a 'wog' sport and that we won't be accepted by the establishment nor achieve our marketing goals because of that perception." 27 Soccer, to be successful, needed an acceptable image of Australianness, one void of ethnicity.

What becomes very clear when reading these texts on ethnic groups, Anglo-Australians, and the nation is that "only a very weak and superficial form of multiculturalism is acceptable in Australian society." ${ }^{28}$ What is ironic is that soccer in Australia had to be "de-ethnicized" before it could be proclaimed by the National Soccer League as an expression of Australian multiculturalism. Multiculturalism, states Danforth, "in this sense is little more than a euphemism for assimilation." 29

Multiculturalism is perceived as such a threat to Australian culture that a number of authors believe that, as white Australians, they can no longer be published. Perera and Pugliese relate how, in order to overcome the "'handicap' of British ancestry," white authors and painters have impersonated "ethnic" or First Nations personalities and have achieved considerable success before they were denounced. ${ }^{30}$ Nearing pathological dimensions, these artists received a fair amount of support from the establishment, even after being outed, blaming a society where "AngloAustralians had become 'the most disenfranchised' citizens of the country." 31

However, not all members of Australian society are willing to tolerate even an insipid form of multiculturalism. Pauline Hanson's extreme right-wing party, the One $\mathrm{Na}$ tion Party, has of late called for the abolition of multiculturalism as the official government policy. The reasons for this are many.

The first is that, according to One Nation Party, "multiculturalism actively encourages separatism." ${ }^{32}$ Hanson claims that prior to the policy of multiculturalism, "migrants were assimilated into mainstream Australia with little disruption." However, since multiculturalism has been in place, it has created ethnic ghettoes, which have generated suspicion in the "wider community."

Second, Hansonites decry the costs of multiculturalism to the taxpayers. Estimated at a cost of $\$ 6.9$ billion, they claim that "the policy of multiculturalism must be abandoned immediately and its infrastructure dismantled." Moreover, "those who wish to celebrate their own culture must do so at their own expense, not at that of the taxpayer. There can only be one Australia and only one Australian flag." The latter comment is possibly a reference to the waving of Greek and Macedonian flags at soccer games, which the Federation banned in 1996.

The One Nation Party discourse is full of contradictions. While they claim that a society cannot survive with "separate societies" within its borders, and that "disharmony, suffering and war in many countries" is the direct result of one culture "trying to impose their laws, religion and beliefs on other peoples of a different culture," they are entirely blind to the fact that they are reproducing this oppression in their own country.

Fourth, the belief that Australia and its culture are under threat is stated in no such ambivalence: "Every variety of culture in Australia today has a mother country where their particular culture can survive and develop. Our unique Australian culture and identity has nowhere else in the world in which to survive. Destroy it here and it is gone forever." Hanson believes that migrants who choose Australia should "have a genuine desire to embrace and enjoy Australia's cultural values, life style and freedoms as they have evolved" (emphasis added). This implies that newcomers to Australia are free to enjoy existing culture, but not to bring their own or expect their own to be recognized. Followed to its logical conclusion, retroactively, such a policy means that First Nations culture is the only one that should be celebrated since it is the only one that existed in Australia prior to colonization. Hanson takes care of that dilemma by erasing First Nations presence from the colonial map. She does this by listing, alongside the British, the convicts, and the Chinese, Aboriginal "migration" to Australia. By placing First Nations Peoples on an equal footing with immigrant groups and white settlers, Hanson dehistoricizes them and removes them from the collective consciousness, conveniently erasing from memory hundreds of years of genocide.

This is common practice among white settler society; it is a historical amnesia necessitated by the colonial project. As Kay Schaffer writes:

...the history of Australia was built on the notion of the land as terra incognito, terra nullius - unknown, untamed, unoccupied and open to the progressive mastery of colonization. That process of colonization relied upon the imagined absence of indigenous peoples, and also at the same time inscribed them in "our" history as remnants of a static primordial past. ${ }^{33}$

Although there are many tropes at his disposal, including the Aboriginal as savage, devoid of rights and incapable of government, the white settler always calls on the trope of erasing Aboriginals from the land in order to facilitate the rewriting of history devoid of spilled blood. 
Perhaps the cleverest spin on the anti-immigration rhetoric is that leveled by Hanson and others around issues of ecology and sustainability. There are a number of organizations opposed to immigration on grounds that Australia cannot sustain any further growth. However, for groups such as Australians against Further Immigration, "so-called ecological concerns are but a very thin veil for a more-thanobvious racist nationalist agenda of excluding a particular part of the world from the White-imagined nation. ${ }^{34}$

On One Nation's web site, one repeatedly reads that Australia is the "oldest driest continent," suffering severe soil degradation and climatic uncertainty. Moreover, with "only $10 \%$ of our huge land mass" being arable, Australians are putting their country at risk by reducing the goods available for export. Hanson goes on to decry the lack of reliable water supply and the overwhelming growth of cities, using the example of Los Angeles as a threat of what is to come should Australians not act now. However, attempts to downplay the anti-immigrant sentiment are quickly lost as Hanson states that government policy will lead to the "Asianization of Australia," and that with 70 per cent of new immigrants coming from Asia, within twenty-five years, "Australia will be $27 \%$ Asian."

Viewed in this light, racism in Australia emerges as "constitutive and not marginal to the construction of a white and Anglocentric Australian national identity." ${ }^{35}$ Moreover, playing on the perceived threats from abroad and within, Hanson's call for compulsory military service must be seen "not only as a call to mobilize against a threat from the Asian North, but also as symptomatic of a fear to protect against the Asian alien who is already within the nation's borders." ${ }^{36}$

Academics are not exempt from such inflammatory discourse, contributing to the fear of the invading Other. Irwin Stelzer, in an attempt to propose an immigration policy for the future, states that assimilation must be the chosen path for newcomers to a country. Moreover, perpetuating the "white nation under threat" rhetoric, he states that "respect for ethnic origins and traditions must not be allowed to destroy the cultures of the countries that receive immigrants fleeing from less attractive place." ${ }^{37}$ (emphasis added). In this way, Stelzer, Hanson, and the "disenfranchised" Anglo-Australians perpetuate the myth that the White nation is being flooded by the Other, in a reverse colonialism.

\section{“The Right to Protect Its Borders"}

Having examined the discourse surrounding the "threats" facing Australian culture, we now move on to the second trope, that of Australia's right to protect its borders. This is a natural sequence of events: if one believes that one is under attack, one will naturally want to defend oneself. From
Howard, the Prime Minister, down to the average racist, Australians decry the right to protect themselves from invading hordes. Addressing Parliament during the Tampa crisis, Howard said the following: "Every nation has the right to effectively control its borders and to decide who comes here and under what circumstances, and Australia has no intention of surrendering or compromising that right." 38

Although Australian politicians and academics are always acting as if their country were being prevented from managing its internal affairs, the reality is that since 1992, when detention became automatic for all "illegal" entrants, Australia has passed numerous laws and amended many others in an attempt to ensure no "illegal" migrants reach its shores, and that, should they succeed, their rights would be stripped down to the bare minimum. The mandatory detention policy was set into legislation in 1992 with the Migration Reform Act, and was endorsed through a major parliamentary review in 1994. Mandatory detention applies to visa overstayers - the biggest offenders being from the U.S. and the UK - as well as unauthorized arrivals.

In this way, the law conveniently creates two categories of migrants - one good and one bad, one deserving and one not. This is not particular to Australia. As Razack says, in the context of reforms to the Canadian Immigration Act, "the stringent control to keep people out, all the while claiming to be the most generous, depends for its logic on a careful delineation of who is deserving and who is not." ${ }^{39}$ Creating such categories becomes the only way of justifying in the face of international condemnation, the acceptance of some and the refusal of others. This discourse of fairness and unfairness resonates intensely with the average citizen, which no doubt explains the government's reliance on it. It also helps to situate the illegal refugee in a context of lawlessness and degeneracy, juxtaposed with the nation itself, seen as lawful and civilized.

In 1999, the Migration Act of 1958 was amended to make it an offence "for a person to carry non-citizens to Australia without documentation." ${ }^{40}$ The Migration Legislation Amendment Act made it an offence for a person to "organize or facilitate the bringing or coming to Australia of a group of 5 or more persons where s/he knows they would become illegal immigrants." 41

Also in 1999, the Border Protection Legislation Amendment Act permitted an Australian ship or a customs vessel "to request to board a foreign ship within the 'territorial sea', 'contiguous zone' and, in limited circumstances, the 'high seas." "42 Where the request to board is denied or ignored, a customs vessel may "pursue the foreign ship to 'any place outside the territorial sea of a foreign country."'43 In the process, an officer can use necessary force consistent with international law, including where necessary "and 
after firing a gun as a signal, firing at or into the chased ship to disable it or compel it to be brought to for boarding." ${ }^{44}$ Having boarded the ship, the Act allows the officer to search and arrest anyone that it suspects of contravening Australian migration laws.

Anyone who has seen television footage or newspaper pictures of these boats knows how overcrowded, unstable, and dangerous they are; often, the passengers are rescued after the boat has sunk, and often, the passengers die..$^{45}$ The thought of pursuing a rickety boat in rocky waters in an attempt to board it seems to me to constitute criminal negligence, putting the lives of hundreds of people at risk. Moreover, to anyone familiar with Jewish Holocaust literature, one cannot escape the eerie similarities between Jewish refugees trying to flee Nazi Germany and modern-day refugees and migrants fleeing oppressive regimes and abject poverty. ${ }^{46}$

First, the phrase "Pacific Solution" harks back to the Nazis' "Final Solution," used euphemistically to concoct the extermination of European Jewry as an answer to the "Jewish problem." Interestingly, at the famous 1938 Evian Conference, where this "problem" and its refugee implications were discussed by the international community, the Australian representative, T.W. White, had this to say: "it will no doubt be appreciated that as we have no racial problem, we are not desirous of importing one." ${ }^{47}$ A similar conference was held in February 2002 in Bali, to determine what to do about the "outflow" of refugees on boats to Australia. As this paper illustrates, Australia's reaction is hardly more humane.

Australia has termed its recent approach of directing migrant boats to deserted and decrepit Pacific islands the "Pacific Solution," and this "solution," while stopping short of murder, has the unfortunate similarity of interning its victims. Moreover, as stated above, this "solution" is directly responsible for the capsizing of unsafe ships attempting to reach Australia's shores. In addition, as many activists have pointed out, the tightening of legal migration in Australia and elsewhere is forcing people to resort to unsafe methods of migration, often with tragic results.

Second, the descriptions of conditions aboard migrant ships carrying hundreds of passengers are eerily similar to those of Jews on trains headed to the concentration camps. On these trains, like on these boats, people were crammed like cattle for days on end, with no food and little oxygen. Many thought they would never survive the transport, and many in fact fainted from exhaustion and died on board. They lay in their own and others' urine and feces, all in a strategic attempt to break down their defenses before they arrived at the camps. One could argue that the conditions during the transit that most refugees endure today are so similar to that of slaves or prisoners that it makes it that much easier to treat them as such upon their arrival.

Third, the conditions in detention camps are not unlike those inside work camps. This is a quote from Bruno Bettelheim's The Informed Heart, in which he describes conditions where he was interned:

Prisoners were clothed, housed and fed in total inadequacy; they were expose to heat ... Every single moment of their lives was strictly regulated and supervised. They had no privacy whatsoever, were never allowed to see a visitor, lawyer, or minister. They were not entitled to medical care: sometimes they got it, sometimes not ... No prisoner was told why he was imprisoned, and never for how long. ${ }^{48}$

As we will see later, this is really no different from the conditions under which refugees are detained in Australia. ${ }^{49}$

In October 1999, the Howard government introduced a major change in its refugee protection policy, with the introduction of the Temporary Protection Visa (TPV). As a result, asylum seekers who enter Australia "legally" and who meet the United Nations standard for refugee protection are eligible for permanent protection visas. However, all those who arrive "illegally," whether by air or by sea, can only be granted TPVs. Initially these visas are valid for three years, subject to renewal after that time. TPV holders are eligible to work and to receive some, but not all, medical and other services provided to permanent visa holders. In addition, TPV holders cannot leave Australia, and cannot bring their family for a visit, thus creating economic and emotional strains on family members. The rationale behind the TPV is that should the situation in the migrant's home country improve during the three years, s/he can be sent back. ${ }^{50}$ There is no time here to elaborate on the number of international treaties that this policy contravenes but, needless to say, there are many.

Having failed to stop the outflow of migrants reaching its shores, the Australian government enacted some more laws in 2001 and amended the Migration Act. By "excising" from its migration zone certain territories, Australia has effectively cut off any unauthorized arrival from applying for a visa. Thereby, Ashmore and Cartier Islands, Christmas Island, Cocos Islands, and other offshore resources and installations were all excised from the Australian migration zone. Thus, any refugee arriving on these islands is unable to apply for visas of any kind, unless the immigration minister decides otherwise. Even persons who apply under Australia's offshore refugee and humanitarian program are only eligible for permanent protection after four and onehalf years of a temporary visa. 
Even though the government has said it will process refugee claims on these islands, through UN offices, all paid for by the Australian government, third-country resettlement may be the "preferred outcome." Moreover, this amendment makes it impossible for a migrant to apply for protection if, since leaving his or her country, the migrant has resided "for a continuous period of at least 7 days in a country in which he or she could have sought and obtained effective protection" either from that country or from UNHCR offices located in that country. ${ }^{51}$ This also makes it impossible for TPV holders to apply for permanent visas if they spent at least seven days in a country capable of protecting them. This policy is thus creating a situation of legal limbo for thousands of Australian residents who have no hope of obtaining landed status, unless this amendment is changed. In effect, anyone now arriving "illegally" on Australian soil, via a third country, can never obtain permanent protection in Australia, without ministerial consent.

The result is neatly summarized by the U.S. Committee for Refugees:

The system, therefore, sets up a tiered approach under which, for example, Afghans in Pakistan who are accepted for resettlement in Australia would have immediate access to permanent visas, Afghans accepted from Indonesia would have access to temporary visas with the possibility of permanent visas after four-and-a-half years, and Afghans who arrive unlawfully at Christmas Island would, if found to be refugees, have access only to three-year temporary protection visas. ${ }^{52}$

Other laws or amendments were introduced since 2001. The Migration Legislation Amendment Act 2001 put certain limits on the UN Convention Relating to the Status of Refugees, fearing that Australian courts had been expanding the refugee definition beyond the original intention of the convention.

The Border Protection Act 2001 legally validated all acts that were carried out with regard to the Tampa and the Aceng. Exemplifying its fears of being flooded and of an inability to control its borders, the government claimed that this amendment "puts beyond doubt that decisions about who can and who cannot enter Australia is within the sovereign power of the Australian government." ${ }^{53}$

The Migration Legislation Amendment Act gave government the right to restrict access to judicial review in migration matters in "all but exceptional circumstances," thereby severely limiting access to appeals. A corollary prohibits all class actions in migration litigation.

The assembly of these laws makes Australia the first "western" country to put such "broad and significant legal effort behind the rhetoric of discouraging the 'spontaneous' arrival of asylum seekers in favor of the more orderly, predictable, discretionary, and political system of selecting refugees for resettlement from abroad." ${ }^{\prime 4}$ For the purpose of this essay, it is only one indication of the extent of Australia's fears and anxieties around the "invasion" of its shores by foreigners.

\section{"The Boat-People Are Not Refugees"}

Incessant questioning of the "real" identities of these migrants constitutes the third trope. Pauline Hanson's One Nation Party especially plays on the notion that the boats landing on Australian shores carry not refugees but instead economic migrants. Claiming that migrants bypass other countries of safe haven because "it would be nice to sail on to Australia," Hanson states that Australia is not responsible for people who pay for passage on "organized cruises" that find their way to Australia bypassing other points of refuge. Propagating the mythical concept of the "queue," Hanson's text delegitimizes the refugee and claims all of them to be migrants.

Elected officials are not exempt from this rhetoric. On January 7, 2000, the Premier of Western Australia, Richard Court, said the following about the release of Afghani refugees: "We're not even talking about genuine refugees, we're talking about people who are smart alecs," adding that they "should be turned around straight away." ${ }^{55}$ The Minister of Immigration has not been much better, especially in front of domestic audiences. He has accused TPV holders of "using our good feelings to get money to send out of Australia," and "using the money that is provided for food to buy mobile telephones and then go to charities to try to top up their income." ${ }^{56}$

However, as William Maley argues, the notion of a queue is mythical and exploited by all recalcitrant western nations. The 1951 Convention Relating to the Status of Refugees, he states, does not establish a queue for refugees to join; therefore, to "describe those who arrive by boat as 'queue jumpers' is a complete non-sequitur." ${ }^{57}$ Maley writes in great detail on the political and social realities of most Afghani refugees, emphasizing that Afghan Hazaras, as the most persecuted ethnic group under the Taliban regime, make up the vast majority of Afghani refugees.

Although Australia does have its Refugee and Special Humanitarian Program, applicants face lengthy processing delays of well over a year. This is intolerable in a country like Iran, where many Afghani refugees are located. In December 1999 alone, the Iranian government deported 1,682 Afghani refugees, "more than the total number of Afghans who arrived in Australia by boat over the last ten years." ${ }^{58}$ Moreover, until very recently, there has not been 
an Australian immigration official at the Australian Embassy in Iran to process visa applications. Thus, as Maley suggests, "One can argue that the people smugglers are actually doing a better job than the Australian Government in assisting those Afghans in greatest danger, since the vast majority of those who arrive by boat are found to be Convention Refugees." 59

Second, at the Australian High Commission in Pakistan, because most places are allotted to the Special Humanitarian Programme, for which one must be nominated by a sponsor or have some prior connection to Australia, few Hazaras are chosen.

Third, even those who do find a sponsor can still be denied if their medical situation is precarious, as have many elderly Afghans in Pakistan, according to Maley. Fourth, the presence of Pakistani staff at the Australian High Commission in Islamabad has prompted great suspicion among Afghans, justifiable or not. And finally, the queue to which Australians repeatedly refer is in the hands of Australian immigration officials, and is interpreted at their discretion. This has caused some to say that Australia's resettlement program is not a place in a queue but a ticket in a lottery.

The situation in Indonesia, from which almost all boats arriving in Australia come, is no better for refugees. For starters, at the end of 2001, there were 1.3 million internally displaced persons throughout Indonesia, plus over 100,000 East Timorese refugees in Indonesia's West Timor. Moreover, Indonesia is not a signatory to the 1951 Convention, and therefore has no system for granting refugee status. The UNHCR has an office in Djakarta, with only three staff to assess refugee claims, and very few interpreters for facilitating the interviews; they travel to where refugees are, and if the refugees are found to be Convention refugees, they are brought to the capital. However, integration in Indonesia is not feasible since it lacks an asylum system. Therefore, "resettlement to a third country has become the only available solution and is being pursued by UNHCR." ${ }^{60}$ As of November 2001, as many as 4,000 refugees and asylum seekers were in Indonesia.

This brings us to the point of considering how many refugees who land on Australian shores actually qualify as Convention refugees. According to most estimates, between 92 and 97 per cent of Iraqi and Afghani boat people respectively are eventually found to be Convention refugees, prompting even Australian government officials to question whether detaining them in the first place is not "pointlessly punitive." ${ }^{61}$ What has most people up in arms is the fact that the number of boat people has increased significantly over the past few years. Whereas there were 4,414 boat arrivals from 1989 through 1998, there were almost twice as many, 8,316, from 1999 through 2001. As we will see below, however, these figures pale in comparison to the number of refugees taken in by other countries, both voluntarily and involuntarily.

\section{“Australia Is Leading the Good Fight"}

This brings us to the final trope, that of Australia being the leader in refugee rights, a most generous nation leading the fight against human smuggling. Australia prides itself in being the most generous "western" country to accept refugees, especially because of its record in the 1970s and 1980s when it accepted a number of Indochinese refugees, mostly because of the proximity.

This generosity, however, is perverted by One Nation Party's words. They claim that because Australia can only accept 12,000 refugees per year (about 0.1 per cent of refugees), the policy should be scrapped. Defying all logic, they assert, "any program that helps only $0.1 \%$ of refugees and costs billions of dollars is unfair and immoral." This makes it sound like they care enormously and are outraged that Australia does not take in more refugees. However, immediately following this, they state that they believe in "providing temporary refuge until the danger in the refugee's country of residence is resolved," after which the refugee should be returned. This doublespeak and hypocrisy fills the Web site of Australia's extreme right party.

In official government materials, the message is not so blunt. Howard and his cronies constantly pat themselves on the back for the fact that they are leading the world in strategizing around stopping the flow of human smuggling. Again, though, the doublespeak is obvious for all to see. During the Tampa crisis, Howard, in a ministerial statement, said that something must be done to ensure that people "who seek to be treated as refugees" are fairly assessed. "We stand ready to shoulder our burden in relation to refugees," he goes on to say, "but it must occur in a fair and proper fashion, and plainly what is happening with people-smuggling is that the principle of fairness is being grossly violated." ${ }^{62}$

In this obsessive hunt for "fairness," the people in question, the refugees, get lost in the process. When observing what is happening to these bodies once on Australian soil, what becomes clear is that fairness is the last thing on anyone's mind; discipline and punishment are the agenda of the day here. David Goldberg says, "Degeneracy, then, is the mark of a pathological Other, an Other both marked by and standing as the central sign of disorder." ${ }^{63}$ When investigating the conditions in the detention camps that hold these refugees until their status is determined, one becomes vividly aware of the space of detention as one that marks the bodies as degenerate.

Let us look at Nauru, the tiny desolate Pacific island of 11,500 inhabitants that has received more money from 
Australia in the last year to house and process refugees than they have in the past ten years combined. Although refugees were supposed to be housed in modern, air-conditioned housing built for the Olympic Games, landowners eventually changed their minds after requests for additional compensation were turned down. Instead, they are housed in “'blocks', with a corrugated iron roof, sides of plastic sheeting and green nylon mesh." ${ }^{64}$ To get an idea of how poor this island is, one only has to realize that in recent months, because of cash-flow problems, it has completely run out of essential commodities, such as fruit, flour, sugar, rice, and fuel. No wonder it agreed to house refugees, given the funds that Australia promised!

Numerous international observers to Nauru have been appalled at the conditions that they have seen, ${ }^{65}$ and the Labour Party has called for a judicial inquiry into all detention facilities. Most of these centres are in dry, arid land, with no protection from the humidity or the heat. The government cares so much for these refugees that some are allowed only twenty minutes of freedom every day. According to one observer, instead of treating the refugees for various diseases, "the government is locking them up in camps that are hot, cramped and lacking in facilities for proper hygiene and medical treatment, increasing the risks of spreading and prolonging diseases." ${ }^{66}$ By keeping the refugees in close quarters, the government ensures that diseases like tuberculosis spread among the refugees, after which they can justify their detainment, for the safety of the general population. Marked as contaminated and diseased, the refugees are thus interned as a public health risk.

Of course, the location of these camps, on islands and in Australia proper, guarantees that they never enter in contact with the rest of the population. Woomera, the largest camp in Australia, is hundreds of kilometres inland, in the middle of the Australian desert. Various reports have confirmed that refugees are forced to line up for hours in the blazing sun in order to get food. Not surprisingly, violence and protest are erupting in these camps, with well-known reports of refugees sewing their lips closed in protest. To make these camps even greater sites of violence, there have been numerous reports of sexual assault made by refugees against staff, who are outsourced by the Australian government to a private firm.

Interestingly, refugees are kept in lifeless spaces where nothing grows, where things are either dead or dying, not unlike how First Nations Peoples have been constructed through time. Nauru is an island that, due to years of phosphate mining, not only is largely inhabitable, but also has a lunar topography. And Woomera, in the middle of the Australian desert, is hundreds of kilometres away from civilization, situated in an old army camp. Situated in such environments, the refugee is easily transformed into a lifeless prisoner. I would argue here that the refugee, like Kawash's homeless body, is made into an abject body, "against which the proper, public body of the citizen can stand." ${ }^{67}$ Like the homeless, the refugee is not only "without home, but more generally without place." ${ }^{68}$ Constantly in flux, the refugee has nowhere to go, and is wanted nowhere.

Like the homeless body, the refugee, when "caught," is "squeezed into a tiny space ... cordoned off and sealed." 69 The homeless is caged like an animal, and when s/he rebels, $\mathrm{s} /$ he is greeted with violence. Similarly, while we are more preoccupied with eliminating the homeless body than with the conditions of homelessness, ${ }^{70}$ we are also more concerned with erasing the refugee than with solving the ills that create the conditions for refugee crises in the first place. Thus, the refugee is greeted with "violent processes of containment, constriction, and compression that seeks not simply to exclude or control ... but rather to efface their presence altogether." ${ }^{71}$ Just as Kawash demonstrates how the law has been used to legislate the homeless out of existence, there is ample evidence to demonstrate how the Howard government has relied excessively on the law in order to prevent refugees from landing on Australian shores, and should they succeed, to treat them in such a way as to send a clear message to others contemplating the same move.

\section{Conclusion}

Hannah Arendt, over fifty years ago, wrote that the refugee is "an anomaly for whom there is no appropriate niche in the framework of the general law," an "outlaw by definition," completely at the mercy of the police. ${ }^{72}$ It is indeed ironic that since Arendt wrote this, while numerous international treaties and conventions have been signed to protect refugees and migrants, the social, economic, political, civil, and human rights of these very people have been substantially curtailed. The Australian experience shows to what extent this is true.

Having transgressed the white man's most important law, "thou shall not leave thy land," the refugee is at the mercy of countries whose haste in making laws that legalize their brutal treatment are matched only by the haste with which they would love to send the refugees back to sea. ${ }^{73}$ Just as Kawash's homeless body is marked as "filth," so too is the refugee, through her capture, internment, and treatment while interned. The internment camp, a site of violence, becomes a "racial slum ...doubly determined, for the metaphorical stigma of a black blotch on the cityscape bears the added connotations of moral degeneracy, natural inferiority, and repulsiveness." 74 Thus constructing the refugee as a degenerate site of lawlessness, governments make it 
feasible to treat her like a prisoner. Ironically, one could argue, as Arendt does, that "it seems to be easier to deprive a completely innocent person of legality than someone who has committed an offense." ${ }^{75}$ What Arendt did not realize is that the refugee's greatest offence, the presumption of leaving one's land and, thereby, one's fate, is already committed before she falls into the hands of her "saviour." Instead of being saved, however, the refugee who arrives in Australia is the victim, once again, of human smuggling, this time at the hands of a government that claims to be acting "for their own good."

\section{Notes}

1. Hannah Arendt, "We Refugees," 1943, cited in Nicholas Xenos, "Refugees: The Modern Political Condition," Alternatives 18 (1993): 419-30.

2. Irwin Stelzer, "Immigration Policy for an Age of Mass Movement," Policy 17 (2001-2002): 3-10.

3. This is taken from the One Nation Party Web site, $<$ http:// www.onenation.com>.

4. According to the 1951 Convention relating to the Status of Refugees.

5. Michael Pugh argues that the plight of refugees and migrant smuggling is a welfare issue, not least because thousands perish at sea every year. Michael Pugh, "Mediterranean Boat People: A Case for Co-operation?" Mediterranean Politics 6 (2001).

6. Most of the information from the Tampa incident was obtained from Jana Mason, Sea Change: Australia's New Approach to Asylum Seekers, (Washington, D.C.: U.S. Committee for Refugees / Immigration and Refugee Services of America, February 2002).

7. "Adrift in the Pacific: The Implications of Australia's Pacific Refugee Solution” (Oxfam, February 2002), 9.

8. Ibid., 13.

9. I cannot do justice here to the intricate legal debacle that unfolded during this entire ordeal, and it is worthy of a paper on its own.

10. Radhika Mohanram, Black Body: Women, Colonialism, and Space (Minneapolis: University of Minnesota Press, 1999).

11. Sherene Razack, "Race, Space, and Prostitution: The Making of the Bourgeois Subject," Canadian Journal of Women and the Law 10 (1998): 338-76. Illegal migration, like prostitution, also involves countless numbers of dead bodies which no one wants to talk about.

12. Mohanram, 4 .

13. Ibid., 11.

14. Ibid., 3.

15. Ibid., 15.

16. Alison Bashford, "'Is White Australia Possible?' Race, Colonialism and Tropical Medicine," Ethnic and Racial Studies 23 (2000): 248-71.

17. There is no space here to examine the connection between Australia's foreign economic policy and forced migration; needless to say, they are not unrelated. Saskia Sassen, in Glo- balization and Its Discontents (New York: New Press, 1998) does a great job of linking U.S. economic activity abroad and mass movements of migration, and shows that contrary to what one would expect, mass migration has consistently come from countries where American investment is prevalent.

18. See above, note 16

19. Bashford, 253.

20. Ibid., 247.

21. Cited in William Maley, "Fear of the Dark: Indonesia and the Australian National Imagination," Australian Journal of International Affairs 55 (November 2001): 371-88.

22. Ibid., 385.

23. Ibid., 374.

24. Loring M. Danforth, "Is the 'World Game' an 'Ethnic Game or an 'Aussie Game'? Narrating the Nation in Australian Soccer," American Ethnologist 28 (2001): 363-87.

25. Ibid., 373.

26. Ibid.

27. Ibid.

28. Ibid., 376.

29. Ibid., 378.

30. Suvendrini Perera and Joseph Pugliese, "'Racial Suicide': The Re-licensing of Racism in Australia," Race and Class 39 (1997): $1-19$.

31. Ibid., 9 .

32. All citations from Pauline Hanson or the One Nation Party are taken from their Web site, <http://www.onenation.com>.

33. Cited in Mohanram, 143.

34. Ghassan Hage, White Nation: Fantasies of White Supremacy in a Multicultural Society (Sydney: Pluto Press, 2000), 165.

35. Perera and Pugliese, 10.

36. Ibid.

37. Stelzer, 8 .

38. Ministerial Statement, August 29, 2001.

39. Sherene Razack, "Making Canada White: Law and the Policing of Bodies of Colour in the 1990s," Canadian Journal of Law and Society 14 (1999): 178.

40. Border Protection Bill 2001 (Bills Digest No. 62 2001-2002) at 1 .

41. Ibid.

42. Ibid., 2 .

43. Ibid.

44. Ibid.

45. On October 20, 2001, more than 350 asylum seekers, mostly Iraqi refugees, drowned off the coast of Java. Among the dead were 300 women and children who were under the deck of the overcrowded, sinking vessel.

46. In no way am I comparing the regimes which refugees are fleeing today to Nazi Germany; my point is to compare the conditions during transport and upon arrival.

47. Cited in William Maley, "Security, People Smuggling, and Australia's New Afghan Refugees," Australian Journal of International Affairs 55 (2001): 351.

48. Bruno Bettelheim, The Informed Heart (New York: Free Press, 1960), 109. 
49. William Maley notes that although Hazaras from Afghanistan are fleeing due to economic and cultural persecution, so too were Jews in Germany before they were eventually interned and exterminated. Although I don't want to push the analogy too far, and obviously there are some key differences between modern-day refugees and Jews in Nazi Germany, my entry point in this subject area was reading about the conditions in the boats that transport refugees. My immediate reaction was that to send back a boat full of refugees who have come from so far, and have traveled under such inhuman conditions for so long, constitutes cruel and unusual punishment, and puts us on a par with those who profit from such misfortune as well as with regimes that make it necessary for these people to leave in the first place.

50. In recent times, Australia has, as unofficial policy, offered money to tempt refugees to return to their country. As much as \$3,000 U.S. has been offered to, and accepted by, many Afghanis who have chosen to go back home rather than to rot in a detention centre in Australia.

51. U.S. Committee for Refugees, 36.

52. Ibid.

53. U.S. Committee for Refugees, 37.

54. U.S. Committee for Refugees, 38.

55. Maley, 351.

56. Ibid., 363.

57. Ibid.

58. Ibid., 364 .

59. Ibid.

60. U.S. Committee for Refugees, 13.

61. Adrienne Millbank, "The Detention of Boat People," Current Issues Brief 8 2000-2001, February 27, 2001; online: <http:// www.aph.gov.au/library/pubs/cib/2000-01/01cib08.htm>.

62. Ministerial Statement, August 29, 2001.

63. David Goldberg, "'Polluting the Body Politic': Race and Urban Location," Racist Culture: Philosophy and the Politics of Meaning (Cambridge: Blackwell, 1993): 200. The Australian government came under considerable pressure to explain why it spread rumours of refugees throwing their babies overboard to attract the attention of Coastwatch, long after it knew this was not true. I would argue it did so in order to mark the refugees even before they landed. For more information, see $<$ http://www.truthoverboard.com.

64. U.S. Committee for Refugees, 9.

65. John Pace, former UN High Commissioner for Refugees official, described the situation in Nauru as "hell" and the "Pacific Solution" as "unsustainable and inhumane." John Pace, "Áustralia: Asylum Seekers - Where to Now?" report for Amnesty International, December 5, 2001.

66. Jake Skeers, "Refugees Face 'Hell' in Australia's Offshore Detention Camps," December 27, 2001; online: World Socialist Web site, <http://www.wsws.org/index.shtml >.

67. Samira Kawash, "The Homeless Body," Public Culture 10 (1998): 325.

68. Ibid., 327.

69. Ibid., 330.
70. The political platform of some of Toronto's mayoral candidates is a prime example.

71. Ibid.

72. Hannah Arendt, "The Decline of the Nation-State and the End of the Rights of Man," in The Origins of Totalitarianism (New York: Harcourt, Brace, 1951), 283.

73. "Sink all boats" is a common phrase in Australia.

74. Goldberg, 192.

75. Arendt, "The Decline of the Nation-State," 295.

A social worker in his previous life, Richard Wazana is currently completing an LL.B. at York University's Osgoode Hall Law School. His education includes an Hon. B.A. (York), an M.Ed. (University of Toronto), and an M.S.W. (University of Toronto).

(C) Richard Wazana, 2004. This open-access work is licensed under a Creative Commons Attribution-NonCommercial 4.0 International License, which permits use, reproduction and distribution in any medium for non-commercial purposes, provided the original author(s) are credited and the original publication in Refuge: Canada's Journal on Refugees is cited. 